\title{
Using youth-friendly communication approaches to communicate HIV/AIDS with young people is feasible and acceptable
}

Population Council

Follow this and additional works at: https://knowledgecommons.popcouncil.org/departments_sbsr-rh

Part of the Community Health and Preventive Medicine Commons, Demography, Population, and Ecology Commons, Family, Life Course, and Society Commons, International Public Health Commons, Medicine and Health Commons, and the Public Health Education and Promotion Commons How does access to this work benefit you? Let us know!

\section{Recommended Citation}

"Using youth-friendly communication approaches to communicate HIV/AIDS with young people is feasible and acceptable," APHIA II Operations Research Project in Kenya OR Summary. Nairobi: Population Council, 2011. 


\section{Key findings}

- Majority of students exposed to intervention: Of the students who participated in the endline survey, $84 \%$ had received at least one edition of the comic books. Of these, $87 \%$ thought the stories and messages were educative.

- Students strongly need information on HIV and AIDS: $82 \%$ and $79 \%$ of the students at baseline and endline respectively said they would like to receive information on HIV and AIDS. Over half would like information on how to avoid infection; other information needed include how to access treatment and care; how to live positively if infected and where to get tested; responsible sexual behaviour; sexual negotiation, and how to deal with sexual abuse and peer pressure.

- Intervention led to increases in HIV knowledge: Students who read the comic books had significantly higher levels of knowledge of modes of HIV infection than those who did not. For instance, $72 \%$ of students who obtained and read the comic books knew about HIV infection from mother to child, compared to $49 \%$ of those who did not.

- Intervention led to more discussion about HIV counselling and testing: The proportion of students who had discussed HIV testing and counselling with anyone was higher among those that had read the comic books (54\%) than those who had not (44\%).
Most of the discussions were with friends/classmates, parents/guardian and teachers.

- Intervention led to increase in acceptability of HIV counselling and testing: The proportions of students who said that they would accept testing, counselling or test results were significantly higher at endline among those who had read the comic books than among those who did not. Forty-seven percent of students who had read the comics also reported that their fear of getting tested for HIV had reduced.

- Intervention led to reduced sexual activity: The proportion of students who had sex within the previous one month before the endline survey was lower among those that had read the comic books (25\%) than among those who had not (35\%).

\section{Recommendations:}

- Young people in schools have great need for HIV and AIDS information. The Ministry of Education and its partners should devise ways of providing this information through ageappropriate channels.

- Using youth-friendly communication materials and approaches to communicate HIV and AIDS information is feasible and acceptable to students. Programmes should explore using more innovative approaches to reach young people, to reduce boredom and stimulate interest in the information delivered.

Source: Obare, F, H Birungi et al. 2011. Feasibility of using youth-friendly channels to communicate HIV and AIDS messages to in-school young people in Kenya. APHIA II OR Project Report. Population Council, Kenya

For more information, contact:

Harriet Birungi, Project Director, APHIA II OR Project in Kenya/Population Council, hbirungi@popcouncil.org, www.popcouncil.org (C) 2011 The Population Council, Inc. 